\title{
Garuda Indonesia-Rolls Royce Corruption, Transnational Crime, and Eradication Measures
}

\author{
Satria Unggul Wicaksana Prakasa \\ Universitas Muhammadiyah Surabaya, Indonesia \\ satria@fh.um-surabaya.ac.id
}

\begin{abstract}
The appointment of Emirsyah Satar, former President Director of PT Garuda Indonesia, and former Director of PT Mugi Rekso Abadi, Soetikno Soearjo who was the beneficial owner of Connaught International Pte. Ltd. as an intermediary for bribery against the Emirsyah in the alleged bribery case of aircraft and aircraft engine procurement from Airbus SAS and Rolls Royce PLC by PT. Garuda. Crossborder corruption carried out by Rolls-Royce is not only corruption committed by a private entity, but the case is also related to efforts to recognize the concept of Foreign Affairs Bribery as a new type of corruption. This research aims to find out the corruption as a transnational crime committed by multinational corporations and how inter-state cooperative actions can prosecute corruption cases. Legal questions raised are: (1) how can the United Nations Convention Against Corruption mechanism be used in exposing the Garuda Indonesia-Rolls Royce corruption case as a transnational crime, and (2) what legal remedies which can be applied to punish corruption committed between Garuda Indonesia-Rolls Royce? This study argues that, as part of transnational crime, of course, Garuda Indonesia and RollsRoyce's corruption is an extraordinary crime that is not only detrimental to business practices but also the rule of law in Indonesia and other countries involved. Corruption done by Rolls-Royce, which involved Emirsyah Satar as a former director of Garuda Indonesia, has harmed Indonesia. Thus, Jurisdiction of criminal acts of corruption is needed. It should be under the legal system of corruption eradication in Indonesia. There is a need for interpretation because Indonesia is part of the state which ratified UNCAC through Law No. 7/2006. Therefore, Therefore, recognizing the Foreign Affairs Bribery concept as part of a judge's rechtsvinding (finding of law) of the Criminal Court that multinational/ transnational corporations comply with and respect the rule of law and eradication of corruption in Indonesia. Including making lex specialis (law governing a specific subject matter) related to Foreign Affairs Bribery so that similar cases do not occur in the future for Indonesia.
\end{abstract}

KEYWORDS: Corruption, Transnational Crime, Garuda Indonesia, Rolls-Royce.

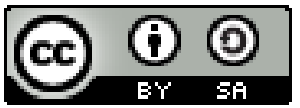

Copyright $\odot 2019$ by Author(s)

This work is licensed under a Creative Commons Attribution-ShareAlike 4.0 International License. All writings published in this journal are personal views of the authors and do not represent the views of this journal and the author's affiliated institutions.

\section{HOW TO CITE:}

Prakasa, Satria Unggul Wicaksana. "Garuda Indonesia-Rolls Royce Corruption, Transnational Crime, and Eradication Measures” (2019) 6:3 Lentera Hukum 413-430.

Submitted: October 12, 2019 Revised: October 28, 2019 Accepted: December 18, 2019 


\section{INTRODUCTION}

The appointment of Emirsyah Satar, former President Director of PT Garuda Indonesia, and former Director of PT Mugi Rekso Abadi, Soetikno Soearjo who was the beneficial owner of Connaught International Pte. Ltd. as an intermediary for bribery against the Emirsyah in the alleged bribery case of aircraft and aircraft engine procurement from Airbus SAS and Rolls Royce PLC by PT. Garuda. According to the Indonesian Corruption Eradication Commission (KPK), Emirsyah in this case allegedly took bribes of $€ 1.2$ million and US $\$ 180$ thousand for a total value of Rp20 billion, and in the form of goods worth US $\$ 2$ million spread across Singapore and Indonesia from leading British manufacturing company Rolls-Royce in the purchase of 50 Airbus SAS aircraft engines from 2005-2014 for PT Garuda Indonesia. ${ }^{2}$

That case is also an inseparable part of the corruption case of the British aircraft engine manufacturer, Rolls-Royce, which has been investigated by the Serious Fraud Office (SFO), an anti-ruling agency of the British Government. ${ }^{3}$ Rolls-Royce admitted that it had committed bribery on a large scale with several overseas governments across three continents. The SFO investigation found that Rolls-Royce committed bribery in several countries, including Indonesia, Thailand, India, Nigeria, Malaysia, China, and Russia between 1989 and 2013. Based on investigations by The Guardian and BBC in 2016, Rolls-Royce entered into business contracts in at least 12 different countries. ${ }^{4}$ Although the SFO stopped investigating the Rolls-Royce bribery case and paid a fine of $\$ 497.5$ million for corrupt behavior covering three decades, seven jurisdictions, and three businesses, ${ }^{5}$ the Indonesian Corruption Eradication Commission (KPK) continued to investigate Emirsyah Satar's case to pursue the parties responsible for corruption carried out by Emirsyah Satar and ensure individuals and multinational corporations as responsible parties in Garuda's corruption case and transnational crime network.

What is Indonesia's position to uphold its jurisdiction? What efforts have been made to accommodate its jurisdiction in national legislation vis-à-vis the United Nations Convention Against Corruption (UNCAC) and other international conventions under the United Nations Office on Drugs and Crimes (UNODC)? What cooperative strategies has KPK-RI implemented, such that similar transnational corruption crimes can be tackled? What efforts have been made for Indonesia to recognize bribery of foreign public officials (foreign bribery) as a corruption crime in

1 CNN Indonesia, "Kasus Suap Garuda, KPK Kembali Periksa Emirsyah Satar," (2019), online: 〈https://www.cnnindonesia.com/nasional/20190807105637-12-419113/kasus-suap-garuda-kpk-

kembali-periksa-emirsyah-satar>.

2 CNN Indonesia, "Kasus Rolls Royce Dihentikan, KPK Tetap Usut Perkara Garuda," (2019), online: 〈https://www.cnnindonesia.com/nasional/20190724133642-12-415049/kasus-rolls-royce-dihentikankpk-tetap-usut-perkara-garuda>.

3 Rob Evans \& David Pegg, "Campaigners condemn closure of Rolls-Royce bribery inquiry," (2019), online: 〈https://www.theguardian.com/business/2019/feb/22/campaigners-condemn-closure-of-rolls-roycebribery-inquiry>.

4 Ibid

5 CNN Indonesia, supra note 2. 
Indonesia? For Indonesian law enforcement to impose criminal charges under Indonesian jurisdiction?

Cross-border corruption carried out by Rolls-Royce is not only part of the corruption committed by private entities, but is also related to efforts to recognize the concept of foreign bribery as a new form of corruption. For Indonesia, as a country that is quite open to foreign investment, we must ask what legal mechanism is most appropriate to deter corporations and uphold the jurisdiction and sovereignty of the rule of law of Indonesia in eradicating criminal acts of corruption. Based on the facts above, the legal issues raised by this research are: (1) how can the UNCAC mechanism be used in exposing the Garuda Indonesia-Rolls Royce corruption case as a transnational crime, and (2) legal remedies used to punish corruption committed between Garuda Indonesia-Rolls-Royce.

This research utilizes the statute approach, a legal research method, to analyze Garuda's corruption cases. The statute approach is a process of engaging with the rule of law and other doctrinal legal principles in order to address the legal issues raised. ${ }^{6}$ This approach moves vertically and horizontally from international and national legal regulations to examine legal rules that are parallel or hierarchical. ${ }^{7}$ Paired with a conceptual approach by analyzing the case based on the doctrine and views of experts, as well as conceptual and theoretical views, this research aims to solve the legal issues raised beyond merely applying a limited statutory approach. ${ }^{8}$

The legal context for analyzing Garuda corruption cases is the study of public international law, particularly about international criminal law. An emphasis on analyzing international conventions will be dominant in this paper.. However, the study of international law does not stand alone, as this paper also uses a criminal law lens. In examining corruption as a rule-based system, criminal law can also explain the function and authority of the KPK-RI in cracking down on the perpetrators of corruption. A multi-dimensional discourse will approach corruption as a transnational legal issue from many angles. Legal materials have been obtained from international legal conventions, national legislation, literature review based on related themes, as well as from several existing cases. In this article, these multidisciplinary sources will be analyzed qualitatively through deductive logic, in which a conclusion is drawn.

\section{UNCAC, INDONESIAN LAW ENFORCEMENT, AND INTERNATIONAL BUSINESS CORRUPTION}

\section{A. Corruption in the International Business Sector}

Corporations have conducted business through corruption, and bribery can provide benefits and profits. However, the decision to engage in corruption impacts the small

\footnotetext{
6 Stephen Ellias \&e Susan Levinkind, "Legal Research How to Find e Understand the Law (12 ${ }^{\text {th }}$ Edition)", (Berkeley: NOLO, 2004) at 258.

7 Peter Mahmud Marzuki, Penelitian Hukum, (Jakarta: Kencana Prenada Group, 2005), at 96-101.

$8 \quad$ Ibid, at $137-140$.
} 
practice of accountability and endangers the corporation's productivity. ${ }^{9}$ Corruption between Garuda Indonesia and Rolls-Royce are precedents in the aircraft engine industry, so it is only fitting that the paradigm of avoiding corrupt practices is a major step in conducting business for both of the aircraft manufacturers. Transparency and accountability in the business sector will create confidence in the market, as well as financial and non-financial benefits in business ventures conducted by corporations.

In order to anticipate corrupt practices, multinational corporations are expected to realize good corporate governance by forming an internal control system for the corporation itself, as well as subsidiaries in various countries. This principle is hereinafter referred to as Enterprise Risk Management (ERM). ${ }^{10}$ Multinational corporations' corrupt practices can be suppressed in such a way, thereby contributing to economic profit. The complaints process is regulated through transparent and accountable measures and corporations that can understand corporations to avoid the threat of corruption risk that threatens business practices carried out in the host countries. It asserts that preventive action should be taken by Rolls-Royce to create an internal control system, to refrain from corrupt practices both against foreign public officials and against fellow competitors in similar businesses, such as the bribery practices used against Garuda Indonesia.

In their book, Corporate Criminal Liability, Mark Pith and Radha Ivory state that law enforcement will face many challenges in proving legal responsibility, especially in corruption cases. ${ }^{11}$ In the Garuda Indonesia and Rolls-Royce cases, it is difficult to identify whether corruption is the corporation's will or only corporate leaders' initiatives, such as Emirsyah Satar, Soetikno Soerarjo, and UK-based Rolls-Royce officials. Law enforcement must also decipher the role of other corporate leaders, involved in the case both actively and passively by giving bribes aimed at expediting the aircraft engine procurement business, only further complicated by cross-jurisdiction in transnational corruption cases.

Maria Krambia-Kapardis provides an explanation related to the challenges for democratic countries that open their markets to the process of preventing and enforcing the law effectively various multinational corporations and their links to business practices that prioritize anti-corruption principles. Government maintenance of a stable market system is required to create a regulation-based system aimed at overseeing corrupt practices in the business sector. ${ }^{12}$ Thus, corruption in the private sector is a priority that should be holistically regulated by national laws. Holistic

9 Debra Satz, "Markets, Privatization, and Corruption, Social Research", Vol. 80, No. 4, Corruption, Accountability, and Transparency (WINTER), The John Hopkins University Press, (2013) pp. 993 1008

10 William P. Olsen, "The Anti-Corruption Handbook: How to Protect Your Business in the Global Marketplace", (New Jersey: John Wiley \& Sons, Inc., 2010), at 55-56.

Il Mark Pith dan Radha Ivory, "Corporate Criminal Liability: Emergence, Convergence, and Risk," (Basel: Springer, 2010), at 6-7.

12 Maria Krambia-Kapardis, "Corporate Fraud and Corruption: a Holistic Approach to Preventing Financial Crises," (Basingstoke: Palgrave Macmillan, 2016), at 40. 
regulation would support free-market competition and avoid the effects of the economic crisis caused by corrupt practices from the business sector.

The increased risk of corruption in the international business sector, particularly among or involving multinational corporations, is likewise challenged by the probability of weak law enforcement in multinational corporations' host countries. It exemplifies in cases of multinational corporations bribing law enforcement or individuals who have enough influence to prevent or thwart the investigation process. ${ }^{13}$ Weak law enforcement can be caused by weak law holding multinational corporations legally responsible, including law enforcement's limited authority over the investigation or prosecution of corruption cases. Therefore, it is necessary to know the state's commitment to and acceptance of UNCAC, as well as related international treaties, in the domestic legal system.

\section{B. UNCAC and Indonesia's Commitment to Eradicating Corruption in International Business}

Indonesia is a party bound by UNCAC, as well as other related international agreements that are relevant to Indonesia's position as parties. ${ }^{14}$ By ratifying UNCAC, Indonesia manifested itself to the international world as capable of and willing or committed to eradicating corruption. ${ }^{15}$ For Indonesia, this commitment is internationally to accommodate UNCAC clauses so that they can be applied and as binding legal provisions in Indonesia. As a crucial point of international legal actions, ratification is needed in order to create a common standard for types of crimes, as well as the types of criminal corruption cases. ${ }^{16}$

As a transnational crime, indeed, the crimes committed by Garuda Indonesia and Rolls Royce in procuring aircraft engines are also closely related to unfair business competition, hampering open global markets and destroying good business joints. In foreign trade and investment, the countries interested in multinational business endeavors should prioritize the principle of sound investment in order to support the growth of foreign investment and trade. ${ }^{17}$ Such a concern is not only relevant but beneficial for Indonesia as a country concerned with economic development. Regarding corruption in the private sector, as was also the case of Garuda Indonesia and Rolls Royce, UNCAC provides that:

Each State Party shall consider adopting such legislative and other measures as may be necessary to establish as criminal offenses when committed intentionally in the course of economic, financial, or commercial activities:

13 Susan Rose-Ackerman, "International Handbook on the Economics of Corruption", (Cheltenham: Edward Elgar, 2006), at 381.

14 Indonesian has ratified on Law No. 7/2006, including conventions and derivative protocols.

15 Indonesian Corruption Watch, Kajian Implementasi Aturan Trading in Influence Dalam Hukum Nasional, (ICW Pres: Jakarta), at 15.

16 Damos Dumoli Agusman, Hukum Perjanjian Internasional: Kajian Teori dan Praktik Indonesia, (Bandung: Refika Aditama), at 31-32.

17 Nick Kochan \& Robin Goodyear, "Corruption: The New Corporate Challenge", (New York: Palgrave MacMillan, 2011), at 2. 
(a) The promise, offering or giving, directly or indirectly, of an undue advantage to any person who directs or works, in any capacity, for a private sector entity, for the person himself or herself or another person, in order that he or she, in breach of his or her duties, act or refrain from acting;

(b) The solicitation or acceptance, directly or indirectly, of an undue advantage by any person who directs or works, in any capacity, for a private sector entity, for the person himself or herself or for another person, in order that he or she, in breach of his or her duties, act or refrain from acting. ${ }^{18}$

Corruption in the private sector has both actively and passively caused economic losses. Article 21 of UNCAC provides an obligation for participating States to carry out criminal charges both for corruption committed between corporations (private) and government (public), as well as corruption committed between two or more corporations (private). It clearly provides a mandate for the prosecutor to bring action/charges against in the private sector in a court of law, including in Indonesia. ${ }^{19}$

UNCAC Article 22 states: "Each State Party shall consider adopting such legislative and other measures as may be necessary to establish as a criminal offense, when committed intentionally in the course of economic, financial or commercial activities, embezzlement by a person who directs or works, in any capacity, in a private sector entity of any property, private funds or securities or any other thing of value entrusted to him or her by virtue of his or her position." ${ }^{20}$ In this regard, states are required to make criminal or statutory policies for the prosecution of individuals and corporate entities. These policies can investigate assets, private funding, or other mechanisms and actions used by a company leader who is believed to engage in private sector corruption. $^{21}$

Corruption in the private business sector is a practice of avoiding existing laws related to auditing, contracts, the supply of machinery, and public tenders. A corporation can be found guilty of either bribery or corruption. Corruption in the business sector can lead to unfair business competition, contractual practices, and practicing bribery and other forms of corruption. Multinational corporations that engage in corruption already have a network of business and its purposes for bribery networks that cross state borders. ${ }^{22}$

\section{Indonesian Legal System Eradicating Corruption in Private Sectors}

In the Indonesian legal system, besides the Corruption Eradication Act (Corruption Act/Law No. 20 of 2000), the Money Laundering Act (TPPU Law/Law No. 8/2010), the

18 See Art.2l UNCAC

19 KPK, Identification Gap Analysis between laws/regulations of the Republic of Indonesia and United Nations Convention Against Corruption, (Jakarta: KPK Publisher, 2006), at 30-31.

20 See Art.22 UNCAC

21 UNODC, "Legislative Guide for the Implementation of the United Nations Convention Against Corruption," (New York: UN Publishing, 2006), at 99.

22 Robert \& Johnson, et.al, The Struggle Against Corruption, (Basingstoke: Palgrave Macmillan, 2004) at 5. 
Law concerning the Prohibition of Monopolistic Practices and Unhealthy Business Competition (Law Number 5/1999), two key pieces of legislation regulate private sector corruption. Presidential Regulation No. 13 of 2018 concerning Application of the Principle of Recognizing Beneficiary Owners of Corporations in the Framework of Preventing and eradicating Criminal Acts of Money Laundering and Criminal Funding of Terrorism and Supreme Court Regulation No. 13 of 2016 concerning Procedures for Handling Criminal Acts by Corporations facilitate corruption eradication performance on behalf of corporations and accommodate judicial processes involving corporations. Domestic legislation is an essential capital for in-state overcoming private sector corruption for Indonesian and foreign legal entities.

In Indonesian law, a criminal act of corruption for which corporations can be held accountable must fulfill three critical elements:

(1) The existence of a criminal act of corruption committed, and the crime is a criminal offense that can be accounted for by the corporation;

(2) Perpetrators of crimes are people who have a work relationship or other relationship with the corporation both alone and together; and

(3) The crime is committed in a corporate environment. ${ }^{23}$

As an instance of corporate corruption, legal liability ofEmirsyah Satar-former President Director of PT Garuda Indonesia and former Director of PT Mugi Rekso Abadi-and Soetikno Soearjo, owner of Connaught International Pte, is a criminal liability within the scope of Indonesian jurisdiction. ${ }^{24}$ Therefore, inquiries and investigations carried out must refer to the applicable procedural law. ${ }^{25}$

To serve criminal charges to the Rolls-Royce corporation-which is foreign a corporation based in the UK-for bribing public officials and foreign private entities, a cooperative international effort is required. ${ }^{26}$ Indonesia's legal jurisdiction is too limited to crack down on transnational corruption on its own. As a result, there is a strong commitment to resolving Garuda Indonesia and Rolls-Royce's corruption in the context of transnational criminal corruption. The question remains: how can both international and domestic legal mechanisms, especially the Indonesian legal system, resolve this corruption case?

\section{INTERNATIONAL COOPERATION FOR TRANSNATIONAL CRIMINAL LIABILITY}

\section{A. Transnational Crimes}

3 See Art. 20 The Eradication of Corruption Act.

24 Agustinus Pohan, et.al, Panduan Teknis Penyelidikan dan Penyidikan Terhadap Korporasi dalam Tindak Pidana Korupsi, (Jakarta: KPK-RI, 2018), at 19.

$25 \mathrm{Ibid}$, at 20.

26 Dandurand, Yvon, "Strategies and practical measures to strengthen the capacity of prosecution services in dealing with transnational organized crime, terrorism, and corruption," Crime, Law and Social Change; Dordrecht Vol. 47, Iss. 4-5, (Jun 2007): 225-246. 
One of the biggest challenges in the international world is identifying what constitutes a transnational crime, what distinguishes it from international crime, and how this terminology has implications for the types of crime and which legal mechanisms are most appropriate for taking action. Transnational crime can never be separated from cross-border criminal jurisdiction of this type of crime. Transnational crime is very different from international crime, which is closely related to international security threats, such as genocide, war crimes, and crimes against humanity regulated by the 1998 Rome Statute. ${ }^{27}$

Transnational crime is defined by the United Nations Convention against Transnational Organized Crime (UNTOC) as a crime that is carried out in a structured manner, committed together for all states member, and is intentional models of crime of more than one State. The crimes affect multiple countries and feature the common elements of a crime: planning, preparation, and direct control of crimes in other countries. ${ }^{28}$ UNTOC emphasizes that every nation must take action in their legal systems against organized transnational corruption crimes and their relationship to foreign public officials, including making specific legal regulations for transnational crimes. ${ }^{29}$ UNTOC also includes the obligation for all states to take preventive measures, detect, and impose penalties for corruption involving foreign public officials with consideration for their ability to discriminate in international relations. ${ }^{30}$

The term "multi-jurisdictional transnational crime" impacts the determination of which legal mechanisms are authorized to take action against transnational crimes; which law enforcement officers are authorized to investigate, which courts are authorized to try such cases, and so on. Thus, globalization, which demands a 'borderless market access' state, has destructive implications for the emergence of transnational crime. Organized transnational crime aims to discriminate in global market competition. Transnational crime breaks through sovereignty, citizenship, and the nation-state. ${ }^{31}$

As part of globalization's development, multinational corporations doing business in various countries have impacted which types of transnational crime can be categorized as corruption. Corruption by international corporations affects the course of a country's economic growth, damages the integrity of the international market, and becomes a global problem. ${ }^{32}$ Multinational corporations' corruption crimes committed

27 Philip Reichel \& Jay Albanese, The Handbook of Transnational Crime and Justice, (London: Sage Publishing, 2014) at 5.

28 See General Assembly resolution 55/25 of 15 November 2000 United Nations Convention against Transnational Organized Crime (UNTOC), Palermo, Italy, in December 2000. Indonesian has ratified into Law No.5/ 2009.

29 See Art. 8 (2) UNTOC.

30 See Art. 9 (2) UNTOC.

31 Sharon Pickering \& Jude McCulloch, Beyond Transnational Crime.Social Justice; San Francisco Vol. 34, Iss. 2, (2007): 1-3.

32 W. Huisman, et.al, Histories of Transnational Crime, (New York: Springer, 2015), at 160. 
are increasing, including not only bribing foreign public officials but also corruption between multi-state or other conglomerate. ${ }^{33}$

In addition to the punishment approach, other approaches are needed to uncover networks of organized crime, including business and political networks, so that prevention and eradication efforts can then be formulated. ${ }^{34}$ Transnational corruption networks involving politicians, law enforcement, and foreign public officials are a clear enough requirement to categorize transnational corruption as part of organized transnational crime. ${ }^{35}$ Transnational crime and its relationship to private, business sector corruption needs to be further analyzed in order to understand the difference between corruption crimes generally, and how corporations as legal entities can be held legally accountable through international legal mechanisms and national law. ${ }^{36}$

Transnational crime and corruption will be challenged by limited law enforcement authority and cross-border jurisdiction issues that are quite sensitive because they relate to inter-state interests. Cooperative action is necessary to eradicate these challenges. Only then can transnational corruption crimes can be dealt with comprehensively.

\section{B. Transnational Crimes and Corruption in the Business Sector}

Transnational corporate bribery carried out between Rolls-Royce and many parties, including public officials and fellow business people, can be defined as direct involvement both active (such as giving/promising/beneficial) or passive (such as receiving/asking), involving the corporation to create profits in business, especially for multinational corporations pursuing international business transactions. Such transactions include ease of licensing from the relevant country's government or providing facilities in winning tenders and business contracts in countries where corrupt practices are carried out. Corrupt business sector activities violate the principles of good business governance, as presented both in relevant state laws and international legal regulations. ${ }^{37}$

To conceptually examine the practice of corruption/bribery committed by corporations against public officials and fellow business competitors (private entities), the comparison matrix can be described as follows:

\section{\begin{tabular}{|l|l|l|l|l|} 
Form of & Origins of & Recipients of & Transnational & Active/passive
\end{tabular}}

33 Klaus von Lampe, Transnational organized crime challenges for future research, Crime Law Soc Change, (New York: Springer. 2012) at 179-194.

34 Heinrich-Böll-Stiftung, Regine Schönenberg (ed), Transnational Organized Crime: Analyses of a Global Challenge to Democracy, (New York: Springer Verlag, 2013), at 62-63.

35 John McFarlane, Transnational crime: corruption, crony capitalism, and nepotism in the twenty-first century, (Sydney: ANU Press, 2013), at 132.

36 Mitchell Congham, Peter Bell, \& Mark Lauches, Policing Transnational Organized Crime and Corruption: Exploring the Role of Communication Interception Technology, (London: Palgrave Macmillan, 2013), at 13-14.

37 Nicholas Lord, Regulating Corporate Bribery in International Business: Anti-Corruption in the UK and Germany, (Burlington: Ashgate Publisher, 2014), at 18. 


\begin{tabular}{|c|c|c|c|c|}
\hline $\begin{array}{c}\text { Corruption/ } \\
\text { Bribery }\end{array}$ & $\begin{array}{c}\text { Corruption / } \\
\text { Bribery }\end{array}$ & $\begin{array}{c}\text { Corruption / } \\
\text { Bribery }\end{array}$ & / Domestic & \\
\hline $\begin{array}{c}\text { Public Office } \\
\text { Bribes }\end{array}$ & $\begin{array}{c}\text { Corporation } \\
\text { (For example, } \\
\text { Board of } \\
\text { Directors, } \\
\text { Employees, } \\
\text { Subsidiaries, } \\
\text { Intermediaries, } \\
\text { Agents) }\end{array}$ & $\begin{array}{l}\text { Public officials } \\
\text { (Diplomats in } \\
\text { relevant State } \\
\text { representatives } \\
\text {, politicians, } \\
\text { law } \\
\text { enforcement } \\
\text { officials) }\end{array}$ & Both & Both \\
\hline $\begin{array}{l}\text { Corruption / } \\
\text { Private Bribery }\end{array}$ & $\begin{array}{c}\text { Corporation } \\
\text { (For example, } \\
\text { Board of } \\
\text { Directors, } \\
\text { Employees, } \\
\text { Subsidiaries, } \\
\text { Intermediaries, } \\
\text { Agents) }\end{array}$ & $\begin{array}{c}\text { Competitor } \\
\text { company } \\
\text { directors, } \\
\text { competitor } \\
\text { vendors/contra } \\
\text { ctors }\end{array}$ & Both & Both \\
\hline
\end{tabular}

Table l. The Concept of Transnational Corruption and Bribery ${ }^{38}$

If we look at testing the concept, the Garuda Indonesia and Rolls-Royce corruption case is part of the corruption/bribery concept in the private sector. It is very relevant to corruption relating to foreign officials, including public officials and business competitors. The agreement of the OECD Convention on Combating Bribery of Foreign Public Officials in International Business Transactions aims to set a global standard for cracking down on transnational corruption offenders. The actions that became a pressure point for the agreement were prevention, criminal proceedings, international cooperation, and asset recovery, as well as eradication of the threat of corruption and its relationship with foreign public officials in multinational business practices.

The OECD Convention Against Bribery of Public Officials in International Business Transactions clearly defines a uniform understanding of criminal snares for corporations that commit corruption across national borders: the practice of crime by giving, promising, receiving anything that gives rise to economic benefits. The actors involved will be held accountable before the law, in their capacity as public officials, including the families of these public officials. ${ }^{39}$ As a result, the legal regulations made

\footnotetext{
38 Ibid, at 19.

39 Kathleen A. Getz, The Effectiveness of Global Prohibition Regimes: Corruption and the Anti-Bribery Convention. A. Business and Society; Chicago Vol. 45, Iss. 3, (Sep 2006): 254-281.
} 
by the OECD act as a guideline for all parties to refrain from engaging in corrupt practices in business activities carried out by multinational corporations. ${ }^{40}$

The OECD Convention Against Bribery of Public Officials in International Business Transactions is not widely agreed upon, so recognition of these international agreements is vital as a basis for legal compliance in international business practices. ${ }^{41}$ Until May 2018, there were only 43 countries that ratified the international agreement, including home countries from multinational corporations (such as the US). ${ }^{42}$ The effectiveness of and commitment to eradicating corruption in international business will face considerable challenges, despite international efforts to prevent and crackdown on corporate corruption and corrupt behavior. Based on the OECD agreement, domestic legal commitments are required for the agreement to be authoritative, including preparing regulations and law enforcement components to crack down on corruption in international business. ${ }^{43}$

Take, for example, the UK's legal approach to corruption as the home country of Rolls-Royce. The approach taken by the British Government was to create the United Kingdom Bribery Act (UKBA), to implement a regulatory framework for various corporations, both domestic and overseas British corporations are legally required to create an anti-corruption complaint program. The aim is to prevent corruption crimes committed by corporations, respect for legal regulations in the host country, and minimize the risk of corruption in current business practices. ${ }^{44}$

Regarding private sector corruption, foreign bribery is regulated by UNCAC. UNCAC specifically regulates the international business sector, stating:

Each State Party shall adopt such legislative and other measures as may be necessary to establish as a criminal offense, when committed intentionally, the promise, offering or giving to a foreign public official or an official of a public international organization, directly or indirectly, of an undue advantage, for the official himself or herself or another person or entity, in order that the official act or refrain from acting in the exercise of his or her official duties, in order to obtain or retain business or other undue advantage with the conduct of international business. ${ }^{45}$

In this context, corrupt practices carried out by Rolls-Royce Corporations can be categorized as violations of UNCAC, such that preventive measures not carried out by

40 Satria Unggul Wicaksana, "Perdagangan Internasional dan HAM: Relasinya Dengan Sustainable Development," Jurnal Hukum Novelty (2018), at 36-53.

41 Susan Rose-Ackerman, supra note 13 at 381.

42 OECD, "OECD Convention on Combating Bribery of Foreign Public Officials in International Business Transactions," Ratification Status as of May 2018, (2019), online: 〈http://www.oecd.org/daf/antibribery/WGBRatificationStatus.pdf>.

43 Lianlian Liu, The Global Collaboration against Transnational Corruption (Singapore: Palgrave, 2019) at 5-6.

44 Guillermo Jorge \&e Fernando Felipe Basch, How has the private sector reacted to the international standard against transnational bribery? Evidence from corporate anti-corruption compliance programs in Argentina, Crime Law Soc Change (Published by Springer Science+Business Media Dordrecht) (2013) 60:165-190.

45 See Art. 16 UNCAC. 
Rolls-Royce business in giving bribes to Garuda Indonesia directors can be classified as transnational corruption crimes. Therefore, Rolls-Royce is legally liable for bribery. ${ }^{46}$

Rolls-Royce remains legally liable, even though the SFO has declared the investigation over. Subsequently, UNCAC grants states disadvantaged by transnational corruption the right to use domestic legal jurisdiction. Indonesian legal jurisdiction applies in the Rolls-Royce corruption case, as Indonesia has suffered a loss from RollsRoyce. As part of criminal corruption jurisdiction in Indonesia, legal interpretations can be produced by the Court and Judges in charge of Emirsyah Satar's case. The interpretation stands because Indonesia ratified UNCAC through Law No. 7 of 2006. Therefore, Indonesia needs to recognize the foreign bribery concept as part of the Judge's finding (rechtsvinding) that multinational corporations comply and respect the rule of law and corruption eradication efforts in Indonesia.

\section{International Cooperation Measures for Eradicating Transnational Crimes and Corruption in International Business}

UNCAC imposes criminal, civil, and administrative obligations for transnational corruption crimes. ${ }^{47}$ In addition, UNCAC parties should engage in cooperative international efforts to conduct investigations, research, and prosecution, especially

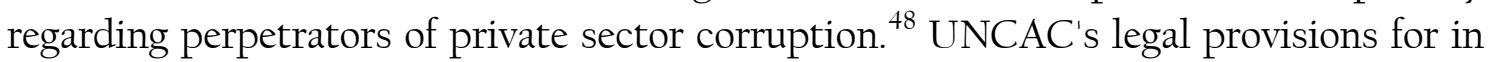
multi-jurisdictional corruption cases' legal processes need to be taken cooperatively together with domestic legislation in every legal process, thereby avoiding the release of corporate legal responsibility for corruption even if outside the home country's jurisdiction.

Efforts that can be taken both between the Indonesian and UK governments to more deeply investigate the handling of corruption between Garuda Indonesia and Rolls-Royce can also be settled through cooperation (Mutual Legal Assistance/MLA), in order to overcome the jurisdictional limitations between host and home countries and cooperation with third-party countries, such as with Singapore. ${ }^{49}$ In the RollsRoyce-Garuda Indonesia corruption case, the Indonesian and UK governments should make a bilateral MLA agreement in order to enforce accountability for corruption. ${ }^{50}$

An MLA agreement requires both governments to appoint a representative for an interstate central authority on corruption eradication (for the UK, SFO, and Indonesia, $\mathrm{KPK}$ ). The central authority operates in investigations and joint prosecution, and in efforts to establish a legal framework together to resolve cases involving corporations, such as Rolls-Royce and Garuda Indonesia, as well as third parties involved in this

\footnotetext{
46 Hönke, Transnational Clientelism, Global (Resource) Governance, and the Disciplining of Dissent, Jana.International Political Sociology; Oxford (2018): 109 - 124.

47 See Art. 26 UNCAC.

48 See Art. 39 UNCAC.

49 See Art. 44 UNCAC.

50 KPK, supra note 19 at 46.
} 
corruption case. ${ }^{51}$ Therefore, the charges of the transnational crime will not fail, even though there has been recognition from Rolls-Royce that they have committed corrupt and bribery practices and provided compensation for corrupt practices as described in the background of this research.

In addition to MLA, which is cooperative and relies on good faith, Indonesia can demonstrate to the international community that its legal system is effective in punishing perpetrators of transnational corruption crimes through adopting an extradition mechanism as a strategy to uphold Indonesian law. In the future, with the use of an extradition mechanism, Indonesia may be more respected, especially by multinational corporations. Extradition practices have been regulated in full in UN General Assembly Resolution No. A/RES/45/116 and are binding, as outlined in UNTOC. $^{52}$ The push for a bilateral agreement between UK and Indonesian governments to take over the legal process carried out by the SFO is part of an appropriate legal settlement mechanism and can be carried out by both countries in order to maintain a good international business culture.

Recovering assets obtained by corruption suspects ${ }^{53}$ is related to: the complexity of both the motive for crime and the flow of funds, is controlled by the network, the existence of system control, and constraints in cooperative efforts only, not an effort to take over authority because of limited authority and the extent to which the parties give up that authority in a criminal jurisdiction of another country. ${ }^{54}$ Assets returned to the state are very important in the context of Rolls-Royce-Garuda Indonesia corruption, especially for Emirsyah Satar's assets held in several countries, including Singapore, as part of money laundering crimes subsidiary to corruption. Financial transactions and reports to the relevant authorities are needed to reveal how much assets the suspect must return, and can be confiscated by the state. ${ }^{55}$

The legal process involving Garuda Indonesia-Rolls Royce, which is transnational in nature, must prioritize the principles of due process of law and legal certainty so that the parties can then be held responsible for corruption and bribery before the legal regime agreed upon by the parties in international agreements, including third-party countries. ${ }^{56}$ As a result, there will be neither fear nor suspicion addressed to law enforcement among countries interested in thoroughly investigating corruption cases and returning state losses.

51 Nicholas Lord, Regulating transnational corporate bribery: Anti-bribery and corruption in the UK and Germany, Crime Law Soc Change (published by Springer Science+Business Media Dordrecht) (2013) at 127145.

52 Jan. S. Maringka, Ekstradisi Dalam Sistem Peradilan Pidana, (Jakarta: Sinar Grafika, 2018) at 126-127.

53 See Chapter V, Article 51-59 UNCAC.

54 Susan Rose-Ackerman, supra note 13 at 16.

55 Peter Alan Sproat, 2007, An evaluation of the UK's anti-money laundering and asset recovery regime, Crime Law Soc Change (Published by Springer Science + Business Media B.V) (2007) 47:169-184.

56 Austen L. Parrish, Domestic Responses to Transnational Crime: The Limits of National Law, Criminal Law Forum (Published by Springer) (2012) 23:275-293. 
Measures to support effective international law cooperation among law enforcement agencies of state parties ${ }^{57}$ are necessary for investigating international corruption cases. KPK, with its investigative mandate, should be provided adequate access to international cooperation networks. ${ }^{58}$ So, too should they have access to addresses, special investigative techniques ${ }^{59}$ such as controlled delivery, electronic and other forms of surveillance, undercover operations, and the admissibility of evidence in court. ${ }^{60}$ Steps to strengthen the work of the Indonesian Commission on Corruption Eradication (KPK-RI) through strengthening authority and cooperation between countries is needed to eradicate transnational corruption carried out by multinational corporations, such as Rolls-Royce. Such measures are suggested in the hopes of healthy foreign business practices that free from corruption.

\section{CONCLUSION}

Of course, the corruption between Garuda Indonesia and Rolls-Royce is an extraordinary case that is not only detrimental to business practices but also the rule of law in Indonesia and other involved countries. UNCAC has provided a road map of how interested countries can take cooperative action to crack down on perpetrators' transnational corruption crimes. Also, as a state harmed by Rolls-Royce, Indonesian judges and courts can claim jurisdiction over the case of Emirsyah Satar, a perpetrator of corruption. Such jurisdiction is secured by Indonesia's position as a state party to UNCAC, ratified through Law No. 7 of 2006. Therefore, it is necessary to recognize the concept of foreign bribery as part of the judges' findings that multinational corporations comply and respect the rule of law and Indonesian efforts to eradicate corruption.

It is not easy because jurisdiction gives a state the exclusive right to crack down on perpetrators of corruption within their borders authoritatively. Some mechanisms and norms need to be strengthened, especially relative to political commitment and legislation both between the government and Parliament of Indonesia (DPR-RI). Specifically, these two bodies need to legislate call for Foreign Bribery as lex specialis and expand the authority of the Indonesian Commission on Eradication Corruption (KPKRI).

The most important lesson from the Rolls-Royce-Garuda Indonesia case is the future development of jurisprudence, especially for international law, transnational crime, and their relation to international business law. In international business practices, it is fitting to respect a host country's legal system, including refraining from engaging in dirty business practices, so that economic growth, industrialization, and various components within it can create good international business. In addition,

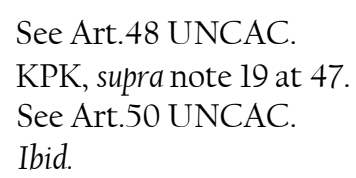


eradicating authority needs to be strengthened in order to anticipate the operating mode of corruption cases, which are becoming increasingly complex and sophisticated. Global society must also encourage cooperation between the countries concerned, better honoring a host country's sovereignty and legal system in cracking down and prosecuting corruption committed by multinational corporations. It is a significant concern, especially for the Indonesian state, which is capable of and willing to resolve the corruption case.

Indonesia must adapt to the development of different, sophisticated, and complex types of corruption that are so sophisticated and complex. One step is to revise the Corruption Act and incorporate norms in both UNCAC and UNTOC, and immediately ratifying them. The OECD Convention is aimed at promoting business and foreign investment in Indonesia, including the aviation sector, which can be carried out well and promote economic growth.

\section{REFERENCES}

Agustinus Pohan, et.al, Panduan Teknis Penyelidikan dan Penyidikan Terhadap Korporasi dalam Tindak Pidana Korupsi, (Jakarta: KPK-RI, 2018).

Adam Edwards \& Peter Gill, Transnational organized Crime: Perspectives on Global Security, (London: Routledge, 2003).

Austen L. Parrish, 2012, Domestic Responses to Transnational Crime: The Limits of National Law, Criminal Law Forum (Published by Springer) (2012) 23:275-293.

CNN Indonesia, "Kasus Suap Garuda, KPK Kembali Periksa Emirsyah Satar" 10th August 2019 https:/www.cnnindonesia.com/nasional/20190807105637-12419113/kasus-suap-garuda-kpk-kembali-periksa-emirsyah-satar.

CNN Indonesia, "Kasus Rolls Royce Dihentikan, KPK Tetap Usut Perkara Garuda" 10th August 2019 https:/www.cnnindonesia.com/nasional/20190724133642-12415049/kasus-rolls-royce-dihentikan-kpk-tetap-usut-perkara-garuda.

Damos Dumoli Agusman $\left(2^{\text {nd }} E d\right)$, Hukum Perjanjian Internasional: Kajian Teori dan Praktik Indonesia, (Bandung: Refika Aditama).

Dandurand, Yvon, 2007, Strategies and practical measures to strengthen the capacity of prosecution services in dealing with transnational organized crime, terrorism, and corruption, Crime, Law and Social Change; Dordrecht Vol. 47, Iss. 4-5, (Jun 2007): 225-246.

Debra Satz, Markets, Privatization, and Corruption, Social Research, Vol. 80, No. 4, Corruption, Accountability, and Transparency (WINTER 2013), The John Hopkins University Press pp. 993-1008.

Guillermo Jorge $\&$ Fernando Felipe Basch, 2013, How has the private sector reacted to the international standard against transnational bribery? Evidence from corporate anti-corruption compliance programs in Argentina, Crime Law Soc Change (Published by Springer Science+Business Media Dordrecht) (2013) 60:165-190. 
Heinrich-Böll-Stiftung, Regine Schönenberg (ed), Transnational Organized Crime: Analyses of a Global Challenge to Democracy, (New York: Springer Verlag, 2013).

Hönke, 2018, Transnational Clientelism, Global (Resource) Governance, and the Disciplining of Dissent, Jana.International Political Sociology; Oxford Vol. 12, Iss. 2, (Jun 2018): $109-124$.

Indonesian Corruption Watch, Kajian Implementasi Aturan Trading in Influence Dalam Hukum Nasional, (Jakarta: ICW Pres).

Jan. S. Maringka, Ekstradisi Dalam Sistem Peradilan Pidana, (Jakarta: Sinar Grafika, 2018).

John McFarlane, Transnational Crime: Corruption, Crony Capitalism and Nepotism in ThetwentyFirst Century, (Sydney: ANU Press, 2013).

Kathleen A. Getz, 2006, The Effectiveness of Global Prohibition Regimes: Corruption and the AntiBribery Convention. A. Business and Society; Chicago Vol. 45, Iss. 3, (Sep 2006): 254-281.

Klaus von Lampe, 2012, Transnational organized crime challenges for future research, Crime Law Soc Change (2012) 58, Springer: New York.

KPK, Identification Gap Analysist Between Laws/Regulations of The Republic of Indonesia and United Nations Convention Against Corruption, (Jakarta: KPK Publisher, 2006).

Lianlian Liu, The Global Collaboration against Transnational Corruption, (Singapore: Palgrave Macmillan, 2019).

Nick Kochan \& Robin Goodyear, Corruption: The New Corporate Challenge, (New York: Palgrave MacMillan, 2011)

Mark Pith dan Radha Ivory, Corporate Criminal Liability: Emergence, Convergence, and Risk, (Basel: Springer, 2010)

Maria Krambia-Kapardis, Corporate Fraud and Corruption: a Holistic Approach to Preventing Financial Crises, (Basingstoke: Palgrave Macmillan, 2016).

Michael Kubiciel \& Anna Cornelia Rink, et.al, International Law and Transnational Organized Crime, (Oxford: Oxford University Press, 2016).

Mitchell Congham, Peter Bell, \& Mark Lauches, 2013, Policing Transnational Organized Crime and Corruption: Exploring the Role of Communication Interception Technology, (London: Palgrave Macmillan, 2013).

Nicholas Lord, Regulating Corporate Bribery in International Business: Anti-Corruption in the UK and Germany, (Burlington: Ashgate Publisher, 2014).

Nicholas Lord, 2013, Regulating Transnational Corporate Bribery: Anti-Bribery and Corruption in the UK and Germany, Crime Law Soc Change (published by Springer Science+Business Media Dordrecht) (2013) 60: 127-145.

OECD, OECD Convention on Combating Bribery of Foreign Public Officials in International Business Transactions, Ratification Status as of May 2018, 15th October 2019 http:/www.oecd.org/daf/anti-bribery/WGBRatificationStatus.pdf. 
Peter Alan Sproat, 2007, An evaluation of the UK's anti-money laundering and asset recovery regime, Crime Law Soc Change (Published by Springer Science + Business Media B.V) (2007) 47:169-184.

Peter Mahmud Marzuki, Penelitian hukum, (Jakarta: Kencana Prenada Group, 2005).

Philip Reichel \& Jay Albanese, The Handbook of Transnational Crime and Justice, (London: Sage Publishing, 2014).

Robert \& Johnson, et.al, The Struggle Against Corruption, (Basingstoke: Palgrave Macmillan, 2004).

Rob Evans \& David Pegg, "Campaigners condemn closure of Rolls-Royce bribery inquiry" 10th

https://www.theguardian.com/business/2019/feb/22/campaigners-condemn-

closure-of-rolls-royce-bribery-inquiry.

Satria Unggul Wicaksana, 2018, Perdagangan Internasional dan HAM: Relasinya Dengan Sustainable Development, Jurnal Hukum Novelty Vol. 9 No. 1, February 2018.

Sharon Pickering \& Jude McCulloch, Beyond Transnational Crime.Social Justice; San Francisco Vol. 34, Iss. 2, (2007): 1-3.

Stefano Manacorda, et.al, 2014, Preventing Corporate Corrupten: The Anti-Bribery Compliance Model, (New York: Springer, 2014).

Stephen Ellias \& Susan Levinkind, Legal Research How to Find \& Understand the Law $\left(12^{\text {th }}\right.$ Edition), (Berkeley: NOLO, 2004).

Susan Rose-Ackerman (ed), International Handbook on the Economics of Corruption, (Cheltenham: Edward Elgar, 2006).

UNODC, Legislative Guide for the Implementation of the united Nations Convention Against Corruption, (New York: UN Publishing, 2006).

W. Huisman, et.al, Histories of Transnational Crime, (New York: Springer, 2015).

William P. Olsen, The Anti-Corruption Handbook: How to Protect Your Business in the Global Marketplace, (New Jersey: John Wiley \& Sons, Inc., 2010). 
430 | Garuda Indonesia-Rolls Royce Corruption, Transnational Crime, and Eradication Measures

This page is intentionally left blank 